\title{
PENENTUAN KOMODITAS UNGGULAN TANAMAN PANGAN BERDASARKAN NILAI PRODUKSI DI KABUPATEN KOTAWARINGIN BARAT
}

\author{
(Determination of the Main Commodity Crops Based of Production \\ in the Kotawaringin Barat Regency)
}

\author{
Novi Nurhayati \\ Program Studi Agribisnis, Fakultas Pertanian Universitas Antakusuma Pangkalan Bun \\ Jl. Iskandar No.63 Pangkalan Bun, Kalimantan Tengah 74112 \\ e-mail : novinurhayati78@yahoo.co.id
}

\begin{abstract}
The purpose of this study was to determine the type of food crops which is the leading commodity in regency Kotawaringin Barat and rate of growth of food crops and contribute production of food crops against the total value of crop production. The data used is secondary data obtained from the Badan Pusat Statistik Kotawaringin Barat Regency. The period of data analyzed in this study were between 2010-2014. The method used is location quotient and analyzed klassen typology. Food crops which is the leading commodity in Kotawaringin Barat Regency is a plant rice, corn and peanuts. The structure of production growth of food crops that include advance and rapidly growing category is the rice plant; which includes fast-growing category is the peanut and soybean, which include forward and slowgrowing category is the corn crop; and that includes commodities lagging behind is cassava, sweet potatoes and green beans.
\end{abstract}

Keywords : competitive commododities, crops

\begin{abstract}
Abstrak
Tujuan dari penelitian ini adalah untuk mengetahui jenis komoditas tanaman pangan yang merupakan komoditas unggulan di Kabupaten Kotawaringin Barat dan laju pertumbuhan tanaman pangan serta kontribusi produksi komoditas tanaman pangan terhadap nilai total produksi tanaman pangan. Data yang dipergunakan adalah data sekunder yang bersumber dari Badan Pusat Statistik Kabupaten Kotawaringin Barat. Periode data yang dianalisis dalam penelitian ini adalah antara Tahun 2010-2014. Metode yang dipergunakan adalah Location Quotient dan analisis Klassen Typology. Komoditas tanaman pangan yang merupakan komoditas unggulan di Kabupaten kotawaringin Barat adalah tanaman padi, jagung dan kacang tanah. Struktur pertumbuhan produksi komoditas tanaman pangan yang termasuk kategori maju dan tumbuh cepat adalah tanaman padi; yang termasuk kategori berkembang cepat adalah tanaman kacang tanah dan kedelai; yang termasuk kategori maju dan tumbuh lambat adalah tanaman jagung; dan yang termasuk komoditas relatif tertinggal adalah tanaman ubi kayu, ubi jalar dan kacang hijau.
\end{abstract}

Kata kunci : komoditas unggulan, tanaman pangan

\section{PENDAHULUAN}

Pembangunan ekonomi merupakan serangkaian usaha dan kebijakan yang bertujuan untuk meningkatkan taraf hidup masyarakat, memperluas lapangan pekerjaan, memeratakan distribusi pendapatan masyarakat, meningkatkan hubungan ekonomi regional dan melalui pergeseran kegiatan ekonomi dari sektor primer ke sektor sekunder dan tersier. Pembangunan ekonomi adalah mengusahakan agar pendapatan masyarakat, disertai dengan tingkat pemerataan yang merata.

Pembangunan di daerah mempunyai peran yang strategis dalam pelaksanaan pembangunan nasional. Pembangunan di daerah dapat mendorong peningkatan 
pemerataan, stabilitas, pertumbuhan dan kesejahteraan masyarakat sebagai pelaku utama pembangunan. Pertumbuhan ekonomi daerah dipengaruhi oleh keunggulan kompetitif, maupun komparatif yang dimiliki oleh daerah tersebut. Pemanfaatan dan pengembangan seluruh potensi ekonomi menjadi prioritas utama yang harus digali dan dikembangkan untuk melaksanakan pembangunan ekonomi daerah secara berkelanjutan.

Struktur perekonomian Kabupaten Kotawaringin Barat didominasi oleh tiga kategori yaitu kategori pertanian, kehutanan dan perikanan; kategori industri pengolahan serta kategori perdagangan, restoran dan hotel. Kategori pertanian, kehutanan dan perikanan memberikan kontribusi terbesar yaitu $28,63 \%$; kategori industri pengolahan memberikan kontribusi sebesar $25,28 \%$ serta kategori perdagangan, restoran dan hotel memberikan kontribusi sebesar 11,82\% (BPS, 2015 ).

Sektor pertanian merupakan sektor penggerak utama dalam bidang agribisnis di Kabupaten Kotawaringin Barat dan merupakan sektor yang dapat ditingkatkan untuk meningkatkan pendapatan masyarakat. Hal ini dapat dilihat dari besarnya kontribusi yang diberikan sektor pertanian dalam pembangunan di Kabupaten Kotawaringin Barat. Sektor pertanian mempunyai kontribusi dalam pembentukan Produk Domestik Regional Bruto di Kabupaten Kotawaringin Barat.

Salah satu sub sektor pertanian adalah sub sektor tanaman pangan. Tanaman pangan merupakan segala jenis tanaman yang dapat menghasilkan karbohidrat dan protein. Jenisjenis tanaman pangan ini meliputi jenis serealia, biji-bijian, umbi-umbian dan tanaman lainnya seperti sukun dan sagu. Tanaman pangan juga merupakan tanaman yang hasil produksinya dapat di gunakan sebagai bahan pangan pokok maupun sebagai bahan pangan pengganti. Tanaman pangan yang ada di Kabupten Kotawaringin Barat meliputi tanaman padi, tanaman jagung, tanaman kacang tanah, tanaman kacang kedelai, ubi kayu, ubi jalar dan kedelai. Berikut ini adalah produksi tanaman pangan di Kabupaten Kotawaringin Barat periode Tahun 2010-2014.

Berdasarkan data pada Tabel 1 terlihat bahwa tanaman padi merupakan jenis tanaman pangan yang produksinya setiap tahunnya mengalami peningkatan. Sedangkan jenis tanaman pangan yang lainnya seperti jagung, ubi jalar, ubi kayu, kacang tanah, kedelai dan kacang hijau, produksinya setiap tahun mengalami penurunan. Dengan mengetahui produksi tanaman pangan yang ada di Kabupaten Kotawaringin Barat, maka dengan menggunakan analisis Location Quotien (LQ) dan analisis Klassen Typology, dapat diketahui apakah komoditas tanaman pangan tersebut merupakan komoditas unggulan di Kabupaten Kotawaringin Barat dan bagaimana laju pertumbuhan tanaman pangan serta kontribusinya terhadap nilai total produksi tanaman pangan.

Tujuan penelitian ini adalah untuk mengetahui jenis komoditas tanaman pangan yang merupakan komoditas unggulan 
Tabel 1. Produksi tanaman pangan di Kabupeten Kotawaringin Barat periode 2010-2014

\begin{tabular}{lrrrrr}
\hline \multirow{2}{*}{ Tanaman Pangan } & \multicolumn{5}{c}{ Tahun } \\
\cline { 2 - 6 } & \multicolumn{1}{c}{2010} & \multicolumn{1}{c}{2011} & \multicolumn{1}{c}{2013} & \multicolumn{1}{c}{2014} \\
\hline Padi & $18.197,95$ & $25.050,19$ & $29.129,47$ & 29.648 & 31.576 \\
Jagung & $4.930,14$ & $4.666,08$ & $2.484,35$ & 1.481 & 1.822 \\
Ubi Kayu & $7.355,17$ & $6.425,8$ & $5.421,07$ & 6.104 & 4.852 \\
Ubi Jalar & $1.347,54$ & 1402,5 & $1.374,08$ & 1.088 & 920 \\
Kacang tanah & 212,26 & 151,35 & 148,99 & 112 & 109 \\
Kedelai & 54,60 & 129,01 & 75,15 & 10 & 5 \\
Kacang Hijau & 26,98 & 9,6 & 7 & 14 & 3 \\
\hline
\end{tabular}

Sumber : Badan Pusat Statistik Kabupaten Kotawaringin Tahun 2010-2015

di Kabupaten Kotawaringin Barat dan laju pertumbuhan tanaman pangan serta kontribusi produksi komoditas tanaman pangan terhadap nilai total produksi tanaman pangan.

\section{METODOLOGI}

Penelitian ini dilaksanakan di Kabupaten Kotawaringin Barat pada bulan Desember Tahun 2015. Bahan yang digunakan dalam penelitian ini adalah data-data sekunder berupa data PDRB Kabupaten Kotawaringin Barat, data Kotawaringin Barat dalam angka serta berbagai macam data sekunder lainnya. Sumber data diperoleh dari Badan Pusat Statistik Kotawaringin Barat. Periode data yang dianalisis dalam penelitian ini adalah antara Tahun 2010-2014. Alat yang menunjang dalam penelitian ini adalah alat tulis dan komputer untuk mengolah data.

Metode analisis data yang di pergunakan dalam penelitian ini menggunakan :

1. Metode Location Quotient adalah suatu perbandingan tentang besarnya peranan suatu sektor/industri disuatu daerah terhadap peranan suatu sektor/industri tersebut secara nasional atau di suatu Kabupaten terhadap peranan suatu sektor/industri secara regional atau tingkat provinsi. Untuk mengetahui komoditi unggulan pertanian daerah Kabupaten Kotawaringin Barat berdasarkan yang mengacu formulasi Bendavid (1991) dengan persamaan sebagai berikut :

$L Q=\frac{P y / P j}{P i r / P r}$ atau $\frac{P y / P i r}{P j / P r}$

Keterangan :

$\mathrm{P}_{\mathrm{ij}}=$ Nilai produksi komoditi pertanian $\mathrm{i}$ pada wilayah kabupaten

$\mathrm{P}_{\mathrm{j}}=$ Nilai total produksi komoditi pertanian kabupaten

$\mathrm{P}_{\text {ir }}=$ Nilai produksi komoditi pertanian pada wilayah provinsi

$\mathrm{P}_{\mathrm{r}}=$ Nilai total produksi komoditi pertanian provinsi

Kriteria pengukuran nilai LQ yang dihasilkan sebagai berikut :

a. Bila LQ > 1, berarti komoditi tersebut menjadi basis atau merupakan komoditi unggulan, hasilnya tidak saja memenuhi 
kebutuhan di wilayah bersangkutan akan tetapi juga dapat di eksport keluar wilayah.

b. Bila LQ $<1$, berati komoditi tersebut tergolong non basis, tidak memiliki keunggulan, produksi komoditi tersebut di suatu wilayah tidak dapat memnuhi kebutuhan sendiri sehingga perlu pasokan atau impor dari luar.

c. Bila LQ $=1$, berarti komoditi tersebut tergolong non basis, tidak memiliki keunggulan, produksi dari komoditi tersebut hanya mampu memenuhi kebutuhan wilayah sendiri dan tidak mampu untuk di eksport.

\section{Uji Statistik}

Setelah data sekunder diolah, kemudian di uji dengan menggunakan uji T-test (onesample statistik), untuk mengetahui kategori komoditi tersebut apakah sebagai komoditi unggulan.

\section{Analisis Klassen Typology}

Analisis Klassen Typology merupakan gambaran pola dan struktur pertumbuhan komoditi pertanian yang dibedakan menjadi empat bagian yaitu komoditi maju dan tumbuh cepat, komoditi maju tetapi tertekan, komoditi berkembang dengan cepat dan komoditi yang relatif tertinggal. Analisis ini bersifat dinamis karena sangat bergantung pada perkembangan kegiatan pembangunan pada kabupaten dan kota yang bersangkutan. Penggunaan dan interpretasi alat analisis Klassen Typology dapat dilihat pada Tabel 2,
Tabel 2. Tipologi pertumbuhan produksi komoditi menurut Klassen

\begin{tabular}{|c|l|l|}
\hline $\begin{array}{l}\text { Kontri- } \\
\text { busi } \\
\text { Pertumbuhan }\end{array}$ & $\mathrm{Y}_{\mathrm{ik}}>\mathrm{Y}_{\mathrm{i}}$ & $\mathrm{Y}_{\mathrm{ik}}<\mathrm{Y}_{\mathrm{i}}$ \\
\hline $\mathrm{r}_{\mathrm{ik}}>\mathrm{r}_{\mathrm{i}}$ & $\begin{array}{l}\text { Komoditi maju } \\
\text { dan tumbuh } \\
\text { cepat }\end{array}$ & $\begin{array}{l}\text { Komoditi } \\
\text { berkembang } \\
\text { cepat }\end{array}$ \\
\hline $\mathrm{r}_{\mathrm{ik}}<\mathrm{r}_{\mathrm{i}}$ & $\begin{array}{l}\text { Komoditi maju } \\
\text { dan tumbuh } \\
\text { lambat }\end{array}$ & $\begin{array}{l}\text { Komoditi } \\
\text { relatif } \\
\text { tertinggal }\end{array}$ \\
\hline
\end{tabular}

\section{Keterangan}

$\mathrm{r}_{\mathrm{ik}}=$ laju pertumbuhan nilai produksi komoditi pertanian $\mathrm{i}$ di tingkat kabupaten.

$r_{i}=$ laju pertumbuhan nilai produksi komoditi pertanian i di tingkat provinsi.

$\mathrm{y}_{\mathrm{ik}}=$ kontribusi komoditi pertanian $\mathrm{i}$ terhadap total produksi tingkat kabupaten.

$\mathrm{y}_{\mathrm{i}}=$ kontribusi komoditi pertanian $\mathrm{i}$ terhadap total nilai produksi tingkat provinsi.

Laju pertumbuhan nilai produksi komoditi $i$ di tingkat kabupaten $\left(\mathrm{r}_{\mathrm{ik}}\right)$ dan tingkat provinsi $\left(\mathrm{r}_{\mathrm{i}}\right)$, serta kontribusi komoditi terhadap nilai total produksi ditingkat kabupaten $\left(\mathrm{y}_{\mathrm{ik}}\right)$ dan kontribusi komoditi terhadap nilai total produksi ditingkat provinsi $\left(\mathrm{y}_{\mathrm{i}}\right)$ dapat dihitung dengan menggunakan rumus sebagai berikut :

$\mathrm{r}_{\mathrm{ik}}=\frac{P i k t-P i k 0}{P i k 0} \times 100 \%$

$\mathrm{y}_{\mathrm{ik}}=\frac{P i k}{P t k} \times 100 \%$

$\mathrm{r}_{\mathrm{i}}=\frac{P i t-P i 0}{P i 0} \times 100 \%$

$\mathrm{y}_{\mathrm{i}}=\frac{P i}{P t} \times 100 \%$

Dimana :

$\mathrm{P}_{\mathrm{ikt}}=$ Nilai produksi komoditi $i$ tingkat kabupaten pada tahun ke- $t$ 


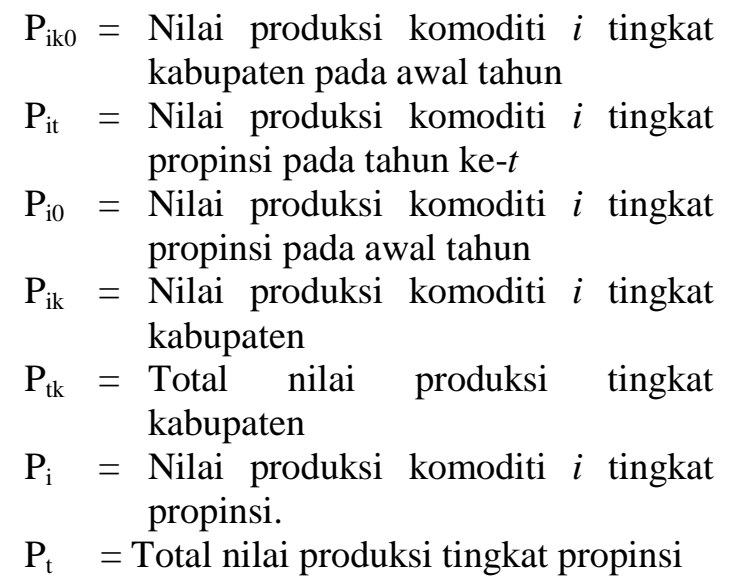

\section{HASIL DAN PEMBAHASAN}

\section{Analisis Location Quotient (LQ)}

Analisis Location Quontient (LQ) merupakan perbandingan tentang besarnya peranan suatu sektor/industri disuatu daerah terhadap peranan suatu sektor/industri tersebut secara nasional atau disuatu kabupaten terhadap peranan suatu sektor/industri secara regional atau tingkat provinsi.

Berdasarkan hasil analisis data, nilai LQ dari komoditas tanaman pangan yang ada di Kabupaten Kotawaringin Barat dapat dilihat pada Tabel 3.

Berdasarkan data pada Tabel 3, dapat dilihat bahwa komoditas tanaman pangan yang mempunyai nilai LQ > 1 adalah komoditas tanaman jagung, tanaman kacang tanah dan tanaman padi. Tanaman pangan yang mempunyai nilai LQ>1 ini berarti bahwa komoditas tanaman pangan tersebut merupakan komoditas tanaman pangan unggulan di Kabupaten Kotawaringin Barat. Hal ini sesuai pendapat Sjafrizal (2008), yang menyatakan bahwa apabila nilai LQ>1 merupakan sektor/industri basis atau unggulan suatu wilayah. Tanaman pangan yang mempunyai nilai LQ>1 ini merupakan tanaman pangan yang hasilnya tidak saja dapat memenuhi kebutuhan Kabupaten Kotawaringin Barat akan tetapi juga dapat di ekspor atau dijual di luar Kabupaten Kotawaringin Barat seperti ke Kabupaten Sukamara, Kabupaten Sampit ataupun di jual ke pulau jawa.

Tanaman pangan yang mempunyai nilai koefisien LQ $<1$ adalah tanaman ubi kayu, ubi jalar, kedelai dan kacang hijau. Tanaman pangan yang mempunyai nilai $L Q<1$ ini merupakan komoditas tanaman pangan yang bukan unggulan, hal ini sesuai dengan pendapat Tarigan (2012), yang menyatakan bahwa apabila nilai koefisien $\mathrm{LQ}<1$ maka sektor/industri tersebut merupakan sektor/industri yang bukan unggulan atau basis suatu daerah. Tanaman pangan yang mempunyai nilai $L Q<1$ merupakan komoditas tanaman pangan yang produksinya tidak dapat memenuhi kebutuhan pangan di Kabupaten Kotawaringin Barat. Untuk memenuhi kebutuhan tanaman pangan tersebut, kabupaten Kotawaringin Barat harus membeli atau mengimpor dari daerah lain baik dari kabupaten tetangga maupun dari pulau jawa.

\section{Analisis Kassen Typology}

Analisis Klassen Typology dapat menggambarkan pola dan struktur pertumbuhan produksi komoditi pertanian yang dibedakan menjadi empat bagian yaitu komoditi maju dan tumbuh cepat, komoditi maju dan tumbuh lambat, komoditi berkembang cepat dan komoditi relalif tertinggal. 
Tabel 3. Hasil analisis Location Quention $(L Q)$ komoditas tanaman pangan di Kabupaten Kotawaringin Barat periode tahun 2010-2014

\begin{tabular}{lrrrrrr}
\hline \multirow{2}{*}{ Tanaman Pangan } & \multicolumn{5}{c}{ Tahun } & \multirow{2}{*}{ Nilai LQ } \\
\cline { 2 - 6 } & \multicolumn{1}{c}{2010} & \multicolumn{1}{c}{2011} & \multicolumn{1}{c}{2012} & \multicolumn{1}{c}{2013} & 2014 & \\
\hline Padi & 0,852667 & 0,992761 & 1,024844 & 1,024778 & 1,193663 & 1,017743 \\
Jagung & 4,871565 & 2,853099 & 2,042306 & 1,463438 & 1,090535 & 2,464189 \\
Ubi Kayu & 0,885853 & 0,731259 & 0,759505 & 0,921975 & 0,545282 & 0,768775 \\
Ubi Jalar & 1,29846 & 0,921408 & 0,94245 & 0,725878 & 0,495273 & 0,876694 \\
Kacang tanah & 1,899227 & 1,103812 & 1,262449 & 1,085248 & 1,003645 & 1,270876 \\
Kedelai & 0,182408 & 0,257302 & 0,288796 & 0,03648 & 0,017433 & 0,156484 \\
Kacang Hijau & 1,465486 & 0,524764 & 0,26434 & 0,819104 & 0,247673 & 0,664273 \\
\hline
\end{tabular}

Sumber : Diolah dari data BPS Kotawaringin Barat Periode Tahun 2010-2015

Berdasarkan analisis data sekunder dengan menggunakan analisis Klassen Typology struktur pertumbuhan masing-masing komoditas tanaman pangan yang ada di Kabupaten Kotawaringin Barat dapat dilihat pada Tabel 4.

Tabel 4. Klasifikasi komoditas tanaman pangan di Kabupaten Kotawaringin Barat menurut Klassen Typology tada tahun (2010-2014)

\begin{tabular}{|c|c|c|}
\hline $\begin{array}{l}\text { Laju } \\
\text { Pertumbuhan }\end{array}$ & $\begin{array}{ll}\text { Kontribusi } & \\
\text { kabupaten lebih } \\
\text { besar dari } \\
\text { kontribusi } \\
\text { provinsi } \\
\left(\mathrm{y}_{\mathrm{ik}}>\mathrm{y}_{\mathrm{i}}\right) \\
\end{array}$ & $\begin{array}{l}\text { Kontribusi } \\
\text { kabupaten lebih } \\
\text { kecil dari } \\
\text { kontribusi } \\
\text { provinsi }\left(\mathrm{y}_{\mathrm{ik}}<\mathrm{y}_{\mathrm{i}}\right)\end{array}$ \\
\hline $\begin{array}{l}\text { Laju } \\
\text { pertumbuhan } \\
\text { kabupaten lebih } \\
\text { besar dari pada } \\
\text { provinsi }\left(\mathrm{r}_{\mathrm{ik}}>\mathrm{r}_{\mathrm{i}}\right)\end{array}$ & $\begin{array}{l}\text { Komoditi Maju } \\
\text { dan Tumbuh } \\
\text { Cepat } \\
\text { Padi }\end{array}$ & $\begin{array}{l}\text { Komoditi } \\
\text { Berkembang } \\
\text { Cepat } \\
\text { Kacang Tanah } \\
\text { dan Kedelai } \\
\end{array}$ \\
\hline $\begin{array}{l}\text { Laju } \\
\text { pertumbuhan } \\
\text { kabupaten lebih } \\
\text { kecil dari pada } \\
\text { provinsi }\left(\mathrm{r}_{\mathrm{ik}}<\mathrm{r}_{\mathrm{i}}\right)\end{array}$ & $\begin{array}{l}\text { Komoditi Maju } \\
\text { dan Tumbuh } \\
\text { Lambat } \\
\text { Jagung }\end{array}$ & $\begin{array}{l}\text { Komoditi } \\
\text { Relatif } \\
\text { Tertinggal } \\
\text { Ubi Kayu, Ubi } \\
\text { Jalar dan } \\
\text { Kacang Hijau }\end{array}$ \\
\hline
\end{tabular}

Berdasarkan Tabel 4 terlihat bahwa, komoditas tanaman pangan yang termasuk kategori maju dan tumbuh cepat adalah komoditas tanaman padi. Laju pertumbuhan tanaman padi di tingkat kabupaten lebih besar apabila dibandingkan dengan laju pertumbuhan tanaman padi pada tingkat provinsi, dan tanaman padi ini mempunyai kontribusi yang besar terhadap total nilai produksi tanaman padi tingkat kabupaten apabila dibandingkan dengan kontribusi produksi tanaman padi terhadap total nilai produksi pada tingkat provinsi. Hal ini diperkuat dengan hasil pengolahan data sekunder yang diambil dari data BPS Tahun 2010-2015, bahwa rata-rata laju pertumbuhan tanaman padi selama periode Tahun 2010-2014 pada tingkat kabupaten adalah sebesar $15,55 \%$ setiap tahunnya, sedangkan rata-rata laju pertumbuhan tanaman padi pada tingkat provinsi adalah sebesar $-7,25 \%$ setiap tahunnya dan rata-rata kontribusi produksi tanaman padi terhadap total produksi tanaman pangan di Kabupaten Kotawaringin Barat adalah sebesar $71,14 \%$, sedangkan rata-rata kontribusi produksi tanaman padi terhadap total produksi tanaman pangan di Provinsi Kalimantan Tengah adalah $69,85 \%$ setiap tahunnya. 
Komoditas tanaman pangan yang termasuk dalam kategori maju dan tumbuh lambat adalah tanaman jagung. Dalam kategori ini, laju pertumbuhan tanaman jagung pada tingkat kabupaten lebih kecil apabila dibandingkan dengan tingkat provinsi. Hal ini dapat terlihat dari hasil produksi tanaman jagung rata-rata dalam kurun waktu 5 tahun (2010-2014), produksi tanaman jagung di tingkat provinsi (40.855 ton) lebih besar bila dibandingkan dengan produksi pada tingkat kabupaten (15.383,57 ton) (BPS, 2010-2014). Kontribusi tanaman jagung mempunyai kontribusi yang besar terhadap nilai total produksi tanaman jagung tingkat kabupaten dibandingkan dengan kontribusi produksi tanaman jagung pada tingkat provinsi. Hal ini dapat dilihat dari pengolahan data sekunder yang bersumber dari data BPS periode Tahun 2010-2015, dimana rata-rata kontribusi produksi tanaman jagung terhadap total nilai produksi tanaman pangan di kabupaten sebesar $8,52 \%$ sedangkan rata-rata kontribusi produksi tanaman jagung terhadap total nilai produksi tanaman panngan di provinsi adalah sebesar $3,50 \%$ setiap tahunnya.

Komoditas tanaman pangan yang termasuk dalam kategori berkembang cepat adalah tanaman kacang tanah dan kedelai. Dalam kategori ini laju pertumbuhan tanaman kacang tanah dan kedelai di tingkat kabupaten lebih besar apabila dibandingkan dengan laju pertumbuhan tanaman padi pada tingkat provinsi, akan tetapi mempunyai nilai kontribusi yang lebih kecil terhadap total nilai produksi tanaman pangan di kabupaten apabila dibandingkan dengan kontribusi produksi tanaman kacang tanah dan kedelai terhadap total nilai produksi tanaman pangan pada tingkat provinsi.

Dalam kategori tanaman yang berkembang cepat, tanaman kacang tanah dan kedelai dalam jangka panjang mempunyai prospek pengembangan yang baik di Kabupaten Kotawaringin Barat, akan tetapi saat ini tingkat kontribusinya terhadap nilai total produksi hasil tanaman pangan pada tingkat kabupaten masih rendah.

Komoditas tanaman pangan yang termasuk dalam kategori relatif tertinggal adalah tanaman ubi kayu, ubi jalar dan kacang hijau. Tanaman pangan yang termasuk dalam kategori relatif tertinggal ini merupakan tanaman pangan yang pertumbuhan dan kontribusinya terhadap total nilai produksi tanaman pangan masih kurang dibandingkan dengan tingkat provinsi. Tanaman ubi kayu, ubi jalar dan kacang hijau merupakan jenis tanaman pangan, akan tetapi untuk Kabupaten Kotawaringin Barat ketiga tanaman tersebut walaupun merupakan jenis tanaman pangan, akan tetapi bukan makan pokok, ataupun pengganti makanan pokok hanya sebagai bahan pangan selingan yang dikonsumsi pada waktuwaktu tertentu. Seperti ubi kayu dapat diolah sebagai keripik, nasi tiwul, tape, kue basah dan lain-lain. Ubi jalar dapat diolah menjadi keripik, kue basah, ataupun sebagai bahan campuran kue kering. Kacang hijau seringnya diolah menjadi bubur kacang hijau. Jadi jenis tanaman 
ubi kayu, ubi jalar dan kacang hijau walaupun merupakan tanaman pangan akan tetapi dalam penggunaannya hanya dimanfaatkan sebagai makanan selingan saja. Jenis makan ini hanya sewaktu-waktu saja di nikmati oleh masyarakat sehingga pertumbuhan tanaman ubi kayu sangat kecil karena hanya untuk memenuhi kebutukan makanan selingan saja.

\section{SIMPULAN DAN SARAN}

\section{Simpulan}

Berdasarkan hasil pembahasan diatas, dapat diambil kesimpulan sebagai berikut :

1. Komoditas tanaman pangan yang merupakan komoditas unggulan di Kabupaten kotawaringin Barat berdasarkan analisis Location Quotient adalah tanaman padi, jagung dan kacang tanah.

2. Struktur pertumbuhan produksi komoditas tanaman pangan yang termasuk kategori maju dan tumbuh cepat adalah tanaman padi; yang termasuk kategori berkembang cepat adalah tanaman kacang tanah dan kedelai; yang termasuk kategori maju dan tumbuh lambat adalah tanaman jagung; dan yang termasuk komoditas relatif tertinggal adalah tanaman ubi kayu, ubi jalar dan kacang hijau.

\section{Saran}

Saran yang dapat diberikan adalah komoditas tanaman pangan yang termasuk unggulan sebaiknya dipertahankan produksinya, sedangkan untuk tanaman pangan yang termasuk bukan unggulan sebaiknya dicarikan solusinya mengapa hasil produksi tanaman pangan tersebut mengalami penurunan produksi setiap tahunnya, sehingga dengan mengetahui permasalahan diharapkan dapat meningkatkan hasil produksi tanaman pangan tersebut.

\section{DAFTAR PUSTAKA}

Badan Pusat Statistik, 2010. Kotawaringin Barat dalam Angka 2010. Kotawaringin Barat In Figures 2010. Badan Pusat Statistik Kabupaten kotawaringin Barat.

Badan Pusat Statistik, 2011. Kotawaringin Barat dalam Angka 2010. Kotawaringin Barat In Figures 2011. Badan Pusat Statistik Kabupaten kotawaringin Barat.

Badan Pusat Statistik, 2012. Kotawaringin Barat dalam Angka 2010. Kotawaringin Barat In Figures 2012. Badan Pusat Statistik Kabupaten kotawaringin Barat.

Badan Pusat Statisik, 2013. Kotawaringin Barat Dalam Angka 2013. Kotawaringin Barat In Figures 2013. Badan Pusat Statistik Kabupaten Kotawaringin Barat.

Badan Pusat Statistik, 2014. Kotawaringin Barat dalam Angka 2010. Kotawaringin Barat In Figures 2014. Badan Pusat Statistik Kabupaten kotawaringin Barat.

Badan Pusat Statistik, 2015 . Produk Domestik Regional Bruto (PDRB) Kabupaten Kotawaringin Barat. Menurut Lapangan Usaha 2010-2014. Badan Pusat Statistik Kabupaten Kotawaringin Barat.

Badan Pusat Statisik, 2015. Kotawaringin Barat Dalam Angka 2015. Kotawaringin Barat In Figures 2015. Badan Pusat Statistik kabupaten Kotawaringin Barat.

Bendavid,1991. Regional and Local Economic Analysis for Practioners. New York. Prager Publisher Inc. 
Sjafrizal, 2008. Ekonomi Regional. Teori dan Aplikasi. Boduose Media. Padang. Sumatra Barat.

Tarigan, Robinson, 2012. Ekonomi Regional. Teori dan Aplikasi. PT Bumi Aksara. Jakarta. 